https://doi.org/10.5817/OS2018-3-8

\title{
VIII Всероссийская научная конференция «Проблемы региональной фольклористики и исторического краеведения (Карповские чтения)»
}

18-19 октября 2018 года в городе Арзамасе на базе Арзамасского филиала Национального исследовательского Нижегородского государственного университета им Н.И. Лобачевского состоялась VIII Всероссийская научная конференция «Проблемы региональной фольклористики и исторического краеведения (Карповские чтения)». Данное мероприятие традиционного характера имело своим объектом, согласно его названию, пропаганду и изучение творческого наследия уроженца Нижегородской области Андрея Васильевича Карпова (1857-1885) - одного из тех, кого называют родиноведом, народоведом, народознатцем.

В оргкомитет конференции было представлено 55 докладов 67 авторов. В центре внимания участников конференции находились проблемы: прошлое и настоящее Нижегородского края; теория и практика исторического краеведения; вклад Нижегородской губернской ученой архивной комиссии в исследование культуры народов Поволжья; выдающиеся нижегородские народоведы XIX-XX веков; фольклор народов Поволжья: традиции и современное состояние; проблемы этнопоэтики и этнолингвистики; современные технологии в литературно-краеведческой работе.

Карповские чтения - 2018 посвящены 200-летию со дня рождения русского писателя П. И. Мельникова-Печерского (1818-1883). Поэтому пленарное заседание открыли два доклада о месте П.И.Мельникова в культурной истории Нижнего Новгорода и России. Н.В. Морохин (Нижний Новгород) в докладе представил П.И. Мельникова как русского писателя и зачинателя большой нижегородской литературы, нижегородской фольклористики, как очеркиста-путешественника, как серьезного исследователя, подготовившего труды по истории Суздальско-Нижегородского княжества, Нижнего Новгорода и городов губернии, как первого русского финно-угроведа, написавшего монографическую работу «Очерки мордвы». Серьезную, но трудно разрешимую проблему затронул в докладе А.А.Кузнецов (Нижний Новгород), рассмотревший исторические мистификации П.И. Мельникова (Андрея Печерского) и предположивший, что ряд сюжетов нижегородской истории придуман П. И. Мельниковым для полного представления нижегородского прошлого. Доклад Т. Б. Радбиля (Нижний Новгород) содержал лингвокультурологическую интерпретацию языковых инноваций на базе иноязычных компонентов в среде 
неформальной интернет-коммуникации. Учёный доказал, что в процессе культурного освоения заимствованных элементов в них возникают культурно-обусловленные коннотативно-оценочные приращения смысла. Иноязычные элементы, таким образом, становятся частью «русского мира». А.Р.Панов (Арзамас) в докладе на основе публикаций в «Нижегородских епархиальных ведомостях» проанализировал деятельность в 1860-1880-е гг. первой общедоступной библиотеки в Арзамасе - духовной публичной библиотеки при Крестовоздвиженской церкви. С. С. Акимов (Нижний Новгород) посвятил доклад рассмотрению трёх икон, исполненных С. Ушаковым для монастыря Флорищева пустынь в Нижегородской области.

На секции «Теория и практика исторического краеведения» обсуждались вопросы изучения истории знаковых мест Нижегородского края, в частности Благовещенской церкви в г. Арзамасе, Починковского государственного конного завода, Серафимо-Понетаевского женского монастыря и др.

Работа секции «Вопросы региональной фольклористики и этнолингвистики» сопровождалась дискуссией, связанной с вопросами языкового воплощения национальной идентичности (концепт «русскость», сказочные аллюзии в творчестве Ф. А. Абрамова, микротопонимы, мифологическая лексика и наименования гаданий в нижегородских говорах и др.).

Секция «Проблемы этнопоэтики, литературы и культурологии» была посвящена вопросам анализа художественного мира П. И. Мельникова-Печерского, Н. Клюева, С. Есенина, М. Волошина, М. Цветаевой, М. Алексеева, В. Пикуля, В. Распутина и др.

Во второй день работы конференции был проведен круглый стол «История и современность Нижегородчины: прототипы героев П. И. Мельникова-Печерского. В Лысковском государственном краеведческом музее состоялся содержательный разговор по вопросам: 1. Нижегородский край в истории России и в художественном творчестве. Персоналии. Объекты. 2. Историко-культурные места, связанные с именем П. И. Мельникова-Печерского, на карте Нижегородской области. 3. Современность творчества П.И. Мельникова-Печерского. 4. Народная память, фольклорные мотивы, исторические предания в творческом наследии П.И. Мельникова-Печерского.

К началу работы конференции издан сборник её материалов, содержащий 50 статей: Карповские чтения ${ }^{1}$ Сборник статей конференции будет опубликован на сайте электронной библиотеки eLIBRARY.ru с постатейной разметкой.

\section{Ольга Валентиновна Никифорова}

1 KUDRIN, Ju. A. (red.): Karpovskije čtenija: sbornik statej. Vyp. 8. Arzamas: Arzamasskij filial NNGU, 2018. $425 \mathrm{~s}$. 